\title{
Susceptibility of In Vitro Melanoma Skin Cancer to Photoactivated Hypericin versus Aluminium(III) Phthalocyanine Chloride Tetrasulphonate
}

\author{
I. M. Ndhundhuma and H. Abrahamse \\ Laser Research Centre, Faculty of Health Sciences, University of Johannesburg, Doornfontein 2028, South Africa \\ Correspondence should be addressed to H. Abrahamse; habrahamse@uj.ac.za
}

Received 13 December 2016; Revised 5 July 2017; Accepted 9 August 2017; Published 25 September 2017

Academic Editor: Xin-yuan Guan

Copyright ( 2017 I. M. Ndhundhuma and H. Abrahamse. This is an open access article distributed under the Creative Commons Attribution License, which permits unrestricted use, distribution, and reproduction in any medium, provided the original work is properly cited.

\begin{abstract}
The sensitivity of human melanoma cells to photoactivated Hypericin (Hyp) compared to aluminium(III) phthalocyanine chloride tetrasulphonate $\left(\mathrm{AlPcS}_{4} \mathrm{Cl}\right)$ is reported in this study. Melanoma cells (A375 cell line) were treated with various concentrations of Hyp or $\mathrm{AlPcS}_{4} \mathrm{Cl}$ alone, for 1, 4, and $24 \mathrm{hrs}$; varying doses of laser irradiation alone (594 or $682 \mathrm{~nm}$ ); or optimal concentrations of PSs combined with laser irradiation. Changes in cell morphology, viability, membrane integrity, and proliferation after treatment of cells were determined using inverted microscopy, Trypan blue cell exclusion, Lactate Dehydrogenase (LDH) membrane integrity, and adenosine triphosphate (ATP) cell proliferation assay, respectively. More than $60 \%$ of cell survival was observed when cells were treated with $2.5 \mu \mathrm{M}$ of Hyp or $\mathrm{AlPcS}_{4} \mathrm{Cl}$ alone at all incubation times or with $5 \mathrm{~J} / \mathrm{cm}^{2}$ of 594 or $682 \mathrm{~nm}$ laser alone. Combination of PSs and respective lasers leads to a statistically significant incubation time-dependent decrease in survival of cells. Flow cytometry using the FITC Annexin V/PI apoptosis kit demonstrated that cell death induced after Hyp-PDT is via early and late apoptosis whereas early apoptosis was the main mechanism observed with $\mathrm{AlPcS}_{4} \mathrm{Cl}-\mathrm{PDT}$. Hyp-PDT compared to AlPcS $\mathrm{Cl}_{4} \mathrm{PDT}$ is indicated to be a more effective cancer cell death inducer in melanoma cells.
\end{abstract}

\section{Introduction}

Excessive exposure of skin to ultraviolet radiation can damage cellular DNA leading to skin cancer $[1,2]$. Other factors that cause skin cancer include skin exposure to carcinogens or having a condition that weakens the immune system [3]. Nonmelanoma skin cancers are curable if detected early [4]. However, melanoma is a rare form of skin cancer that is mostly unresponsive to conventional treatments [5]. Conventional treatments for melanoma are determined by the stage, site of melanoma, and overall health of patient [5]. Surgery is commonly used for early stage melanoma, whereas late stage melanoma may be treated with radiation, immunotherapy, targeted therapy, or chemotherapy [5]. However, these treatments often have a poor prognosis, due to metastatic melanoma resistance; thus the search for suitable cure remains ongoing $[5,6]$.

Photodynamic therapy (PDT) is an unconventional treatment method that has been applied to various forms of cancer and currently is an established form of treatment for nonmelanoma skin cancer. It involves the selective treatment of cancer tissues, using photosensitizer (PS) drug which has been excited with light in the presence of molecular oxygen to produce singlet oxygen and other reactive species to destroy cancer cells. The selective and easy application of photosensitizers (PSs) and light delivery to skin has led PDT to be an increasingly exploited therapy in dermatology [7]. The benefits of PDT are its selective treatment of diseased area, while preserving neighboring normal tissue and the excellent cosmetic effects after treatment [8]. 5-Aminolevulinic acid (ALA $\left(\right.$ Levulan $\left.^{\circledR}\right)$ ); methyl 5-aminolevulinate (MAL $\left(\right.$ Metvix $\left.^{\circledR}\right)$ ); and metatetrahydroxyphenyl chlorine (Foscan/Temoporfin) are currently approved PSs for the treatment of actinic keratosis (AK), basal cell carcinoma (BCC), and neck and head cancers $[8,9]$. Side-effects of burning and stinging have been reported during treatments, and sometimes after treatment transient localized erythema, edema, and crusting have been noted [10]. However, the search for a suitable PS 
and PDT treatment protocol for melanoma and squamous cell carcinoma (SCC) continues [11-14]. The most significantly investigated PSs for PDT in dermatology are Hyp and $\mathrm{AlPcS}_{4} \mathrm{Cl}$. Both PSs have shown great potential in melanoma treatment yet have not been approved for clinical application. Moreover, in vitro studies for the direct comparison of these PSs on melanoma cells in order to establish the suitable PS dose responses for melanoma treatment have not yet been reported.

An ideal PS is characterized by no dark toxicity, low tendency to form aggregates, photostability, absorption of light at longer wavelengths, production of significant amount of singlet oxygen, fluorescent, low absorbance to day light, no retention in healthy tissue, and high uptake in diseased tissue. Phthalocyanines $(\mathrm{Pc})$ are synthetic dyes that have a high molar absorption coefficient in the red part of the spectrum [15]. One of the previously tested PSs, hydrophilic $\mathrm{AlPcS}_{4} \mathrm{Cl}$, has been shown to be a promising PS agent in the PDT treatment of melanoma skin cells $[16,17]$. On the other hand, Hyp is a lipophilic dianthraquinone with a wide absorbance spectrum [18]. It has been used for many years as an antidepressant drug and has also been reported as one of the most potent naturally occurring PDT agents [19]. The scope of this work was to directly compare the susceptibility of human malignant melanoma A375 cells to Hyp and $\mathrm{AlPcS}_{4} \mathrm{Cl}$ in terms of cellular toxicity, subcellular localization, and photodynamic efficacy to possibly assist in the choice and dose of the ideal photoactive PS for melanoma treatment.

\section{Methods}

2.1. Photosensitizers. Hydrophilic aluminium(III) phthalocyanine chloride tetrasulphonate $\left(\mathrm{AlPcS}_{4} \mathrm{Cl}\right)$, molecular weight $895.19 \mathrm{~g} / \mathrm{mol}$, (Frontier Scientific, Logan, UT, USA), and Hypericin, molecular weight $504.44 \mathrm{~g} / \mathrm{mol}$ (Sigma-Aldrich, 56690-1 MG), were used. Stock solutions of $100 \mu \mathrm{M} \mathrm{AlPcS}_{4} \mathrm{Cl}$ were solubilized in Dulbecco's phosphate buffered saline (DPBS; Sigma-Aldrich, D8537) and $2 \mathrm{mM}$ Hypericin were solubilized in dimethyl sulfoxide (DMSO, BDM Merck, Germany) and sterilized using a $0.2 \mu \mathrm{m}$ filter.

2.2. Cell Culture. Cultures of human malignant melanoma (A375 cell line, ATCC number CRL-1619) were grown in the supplemented culture medium consisting of Dulbecco's modified Eagle's medium with L-glutamine and phenol red (DMEM; Sigma-Aldrich, D5796), supplemented with 10\% heat-inactivated fetal bovine serum (FBS; Biochrom GmbH, S0615), 1\% penicillin-streptomycin mixture (Sigma-Aldrich, P4333), and 1\% Amphotericin B (Sigma-Aldrich, A2942). Cell cultures were incubated at $37^{\circ} \mathrm{C}$ in $5 \% \mathrm{CO}_{2}$. When confluent, cells were washed three times with DPBS, detached using TrypLE Express ${ }^{\mathrm{TM}}$ (Gibco Invitrogen, INV 12605028, 4 to $5 \mathrm{ml} / 175 \mathrm{~cm}^{2}$ tissue culture flask), and seeded at $4 \times$ $10^{4}$ cells $/ \mathrm{ml}$ in $3.3 \mathrm{~cm}^{2}$ diameter tissue culture dishes which contained $3 \mathrm{ml}$ of supplemented DMEM and were so further incubated for $24 \mathrm{hrs}$ to allow for attachment.

2.3. PS and Laser Irradiation Dose Response. Dose-response curves using various concentrations of the PSs and different incubation times after irradiation and prior to performing biochemical assays (1, 4, and $24 \mathrm{hrs}$ ) were performed to determine cytotoxicity levels induced by PSs. In order to evaluate biochemical effects, a concentration of $2.5 \mu \mathrm{M}$ of both PSs, Hyp and AlPcS4Cl, which induce approximately $50 \%$ cytotoxicity (ICD50), was selected to observe cellular changes. Attached cells in culture dishes were washed twice with $1 \mathrm{ml}$ DPBS and $1,2.5,5$, and $10 \mu \mathrm{M}$ Hyp or $\mathrm{AlPcS}_{4} \mathrm{Cl}$ were added to $3 \mathrm{ml}$ of freshly replaced supplemented DMEM. Control cells contained cell culture medium without PS. Cells with or without PS were divided into three groups. Group 1 were cells incubated in the dark for $1 \mathrm{hr}$, Group 2 were cells incubated in the dark for $4 \mathrm{hrs}$, and Group 3 were cells incubated in the dark for $24 \mathrm{hrs}$. After respective incubation periods cells were washed twice with $1 \mathrm{ml}$ DPBS and $3 \mathrm{ml}$ of fresh supplemented DMEM was added. All samples were then incubated for $48 \mathrm{hrs}$ after treatment and changes in cell morphology, viability, proliferation, and cytotoxicity were determined, to determine the optimal concentration of each PS to be used in PDT experiments.

Two diode lasers, at wavelengths $(\lambda)$ of 594 and $682 \mathrm{~nm}$ (Oriel Corporation, USA, LREBT00 ROITHI) provided by the National Laser Centre of South Africa, were used to irradiate cells. Both photosensitizer and laser treatment parameters are listed in Table 1 . The laser at wavelength $594 \mathrm{~nm}$ was used to irradiate cells treated with Hyp, while the diode laser at wavelength of $682 \mathrm{~nm}$ was used to irradiate cells treated with $\mathrm{AlPcS}_{4} \mathrm{Cl}$. The laser spot size covered the entire area of the culture dish $\left(3.3 \mathrm{~cm}^{2}\right)$. Prior to performing laser irradiation experiments, a FieldMate Laser Power Meter was used to measure the lasers output power in order to determine laser irradiation exposure times. All irradiation protocols were performed with the lights off so as to eliminate any other external light interference.

In laser irradiation dose-response assays cells in culture dishes were washed twice with $1 \mathrm{ml}$ DPBS and then divided into two groups: Group 1, cells irradiated at a wavelength of $594 \mathrm{~nm}$; Group 2, cells irradiated at a wavelength of $682 \mathrm{~nm}$, with a fluence range of $1,2,5$, or $10 \mathrm{~J} / \mathrm{cm}^{2}$. Control cells in all experiments were cells without PS or not irradiated. After laser irradiation, the DPBS was removed from all the culture dishes and $3 \mathrm{ml}$ of fresh supplemented DMEM was added, following an additional $48 \mathrm{hrs}$ of incubation, after which, changes in cell morphology, viability, proliferation, and membrane integrity were determined, to decide upon the optimal laser dose fluence to be applied at each respective wavelength that was to be applied in PDT experiments.

2.4. Photodynamic Effect. Cells in culture dishes were washed twice with $1 \mathrm{ml}$ DPBS and $2.5 \mu \mathrm{M}$ of either PS in $3 \mathrm{ml}$ of fresh supplemented DMEM was added, as this was determined in previous experiments to be the optimal concentration of each PS to be used in these PDT experiments (Section 2.3). All culture dishes were incubated for an additional 1, 4, or $24 \mathrm{hrs}$. The culture media were then replaced with $2 \mathrm{ml}$ DPBS and cells were then subjected to laser irradiation at $594 \mathrm{~nm}$ (for cells that contained Hyp) or $682 \mathrm{~nm}$ (for cells that contained $\mathrm{AlPcS}_{4} \mathrm{Cl}$ ), at a laser dose of $5 \mathrm{~J} / \mathrm{cm}^{2}$, which was found to be the optimum laser dose fluence in experiments performed 
TABLE 1: Parameters to determine optimal concentration of PS and optimal laser dose on A375 cells.

\begin{tabular}{|c|c|c|c|c|c|}
\hline \multirow{2}{*}{$\begin{array}{l}\text { Parameters } \\
\text { Wavelength }\end{array}$} & \multicolumn{2}{|c|}{ Laser treatment: dose response } & \multicolumn{3}{|c|}{ PS treatment: optimal concentration } \\
\hline & $594 \mathrm{~nm}$ & $682 \mathrm{~nm}$ & PS & {$\left[\mathrm{AlPcS}_{4} \mathrm{Cl}\right]$} & [Hyp] \\
\hline Wave emission & Continuous & Continuous & Concentration & $0 \mu \mathrm{M}$ & $0 \mu \mathrm{M}$ \\
\hline Spot Size & $3.3 \mathrm{~cm}^{2}$ & $3.3 \mathrm{~cm}^{2}$ & & $1 \mu \mathrm{m}$ & $1 \mu \mathrm{m}$ \\
\hline Output power & $124 \mathrm{~mW}$ & $46 \mathrm{Mw}$ & & $2.5 \mu \mathrm{M}$ & $2.5 \mu \mathrm{M}$ \\
\hline Power density & $13.658 \mathrm{~mW} / \mathrm{cm}^{2}$ & $5.067 \mathrm{~mW} / \mathrm{cm}^{2}$ & & $5 \mu \mathrm{M}$ & $5 \mu \mathrm{M}$ \\
\hline \multirow[t]{5}{*}{$\begin{array}{l}\text { Laser fluence (exposure } \\
\text { times) }\end{array}$} & $\begin{array}{c}0 \mathrm{~J} / \mathrm{cm}^{2} \\
(0 \mathrm{~min}, 0 \mathrm{sec})\end{array}$ & $\begin{array}{c}0 \mathrm{~J} / \mathrm{cm}^{2} \\
(0 \mathrm{~min}, 0 \mathrm{sec})\end{array}$ & & $10 \mu \mathrm{M}$ & $10 \mu \mathrm{M}$ \\
\hline & $\begin{array}{c}1 \mathrm{~J} / \mathrm{cm}^{2} \\
(1 \mathrm{~min}, 0 \mathrm{sec})\end{array}$ & $\begin{array}{c}1 \mathrm{~J} / \mathrm{cm}^{2} \\
(3 \mathrm{~min}, 29 \mathrm{sec})\end{array}$ & & & \\
\hline & $\begin{array}{c}2 \mathrm{~J} / \mathrm{cm}^{2} \\
(3 \mathrm{~min}, 08 \mathrm{sec})\end{array}$ & $\begin{array}{c}2 \mathrm{~J} / \mathrm{cm}^{2} \\
(8 \mathrm{~min}, 22 \mathrm{sec})\end{array}$ & & & \\
\hline & $\begin{array}{c}5 \mathrm{~J} / \mathrm{cm}^{2} \\
(6 \mathrm{~min}, 15 \mathrm{sec})\end{array}$ & $\begin{array}{c}5 \mathrm{~J} / \mathrm{cm}^{2} \\
(16 \mathrm{~min}, 04 \mathrm{sec})\end{array}$ & & & \\
\hline & $\begin{array}{c}10 \mathrm{~J} / \mathrm{cm}^{2} \\
(12 \mathrm{~min}, 30 \mathrm{sec}) \\
\end{array}$ & $\begin{array}{c}10 \mathrm{~J} / \mathrm{cm}^{2} \\
(32 \mathrm{~min}, 00 \mathrm{sec})\end{array}$ & & & \\
\hline
\end{tabular}

above. After laser irradiation, the DPBS was removed from all the culture dishes and $3 \mathrm{ml}$ of fresh supplemented DMEM was added. The culture dishes were then incubated for an additional $48 \mathrm{hrs}$. Three control groups were prepared. Group 1 was cells alone; Group 2 was cells with $2.5 \mu \mathrm{M}$ PS and not irradiated; and Group 3 included $2.5 \mu \mathrm{M}$ PS and irradiation at $5 \mathrm{~J} / \mathrm{cm}^{2}$. All samples were incubated for $48 \mathrm{hrs}$ after treatment and changes in cell morphology, viability, proliferation, and membrane integrity were determined.

2.5. Changes in Cell Morphology. Inverted light microscopy (Wirsam, Olympus CKX41) was used to observe and study cellular morphological changes. Images were digitally captured using a SC30 Olympus camera.

2.6. Cell Viability. Trypan blue (Sigma-Aldrich, T8154) dye exclusion viability assay was used to determine the percentage viability of untreated and treated A375 cells. $10 \mu 1$ Trypan blue reagent was added to $10 \mu \mathrm{l}$ of cell suspension and then loaded onto a cell counting chamber slide (Invitrogen, C10283) designed for use with Countess ${ }^{\mathrm{TM}}$ Automated Cell Counter (Invitrogen, C10227). In the Trypan blue assay, cells with an intact cellular membrane do not take up the dye and maintain a clear appearance under the microscope, while damaged cells take up the dye and so appear blue in colour.

2.7. Cytotoxicity. Lactate Dehydrogenase Assay Kit (Cytotox $96^{\circledR}$ assay, Promega G400) was used according to the manufacturer's instructions to measure the Lactate Dehydrogenase $(\mathrm{LDH})$ released from the cytosol into the cell culture media upon cell membrane damage. The membrane integrity of untreated and treated cells was assessed by estimating the amount of LDH present in the culture media. Fifty microliters of reconstituted $\mathrm{LDH}$ reagent was added to an equal volume of cell culture medium from untreated and treated cells and incubated in the dark at room temperature for $30 \mathrm{~min}$.
The calorimetric compound was measured spectrophotometrically at $490 \mathrm{~nm}$ using the PerkinElmer, VICTOR3 ${ }^{\mathrm{TM}}$, microplate reader.

2.8. Cell Proliferation. The CellTiter-Glo ${ }^{\circledR}$ Luminescent Assay (Promega, G7571, Anatech Analytical Technology, Bellville, South Africa) was used according to the manufacturer's instructions to evaluate metabolically active cells by measuring ATP signal of proliferative cells. Fifty microliters of reconstituted reagent was added to an equal volume of cell suspension in a 96-well plate and mixed by placing the plate on a plate shaker for 2 minutes to induce cell lysis. The mixture was then incubated in the dark at room temperature for 10 minutes to stabilize the luminescent signal. The ATP content in each sample was quantified by recording luminescence using the PerkinElmer, VICTOR3 Multilabel Counter (model 1420) in relative light units (RLUs).

2.9. Mode of Cell Death. The FITC Annexin V Apoptosis Detection Kit (BD Pharmingen ${ }^{\mathrm{TM}}$, 556547) was used to detect either early/late apoptotic or necrotic modes of cell death by flow cytometry. In apoptotic cells, the membrane phospholipid phosphatidylserine, which is normally found in the internal portion of the cell membrane, becomes translocated to the outer leaflet of the plasma membrane, thereby exposing phosphatidylserine to the external environment. Annexin V is a calcium-dependent phospholipid binding protein that has an affinity for phosphatidylserine and is useful in identifying apoptotic cells, whereas Propidium Iodide (PI) is used to identify necrotic cells. A375 cells after PDT treatment were washed twice in $200 \mu \mathrm{l}$ PBS and detached using TrypLE Express (Gibco Invitrogen, INV 12605028). Cells were then resuspended in $200 \mu \mathrm{l}$ Binding Buffer (1x) at a cell density of $1 \times 10^{6} / \mathrm{ml}$, after which $5 \mu \mathrm{l}$ FITC Annexin V and $5 \mu \mathrm{l}$ PI were added to cell suspension and vortexed. Stained cell samples were incubated for $10 \mathrm{~min}$ at room temperature and $200 \mu \mathrm{l}$ of 


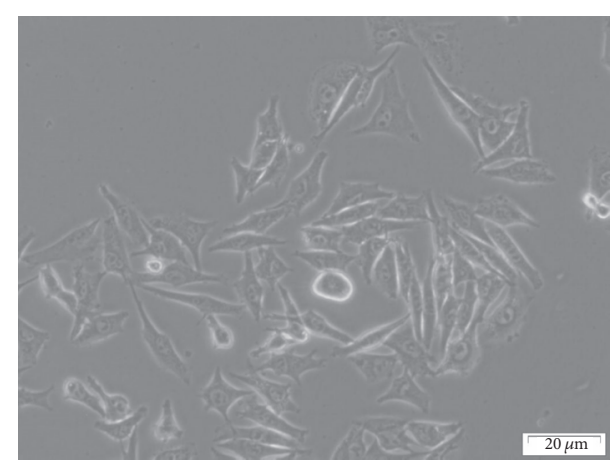

(a)

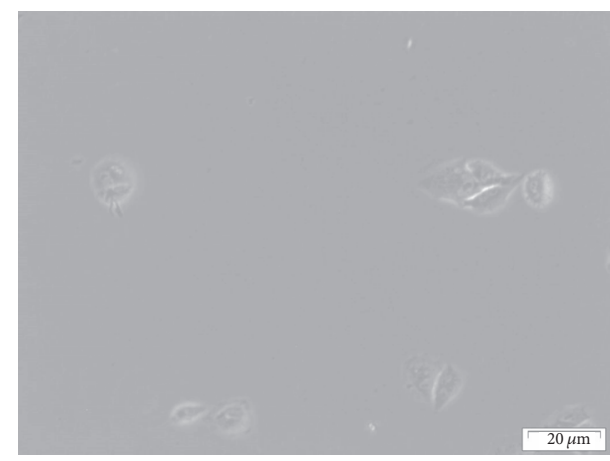

(c)

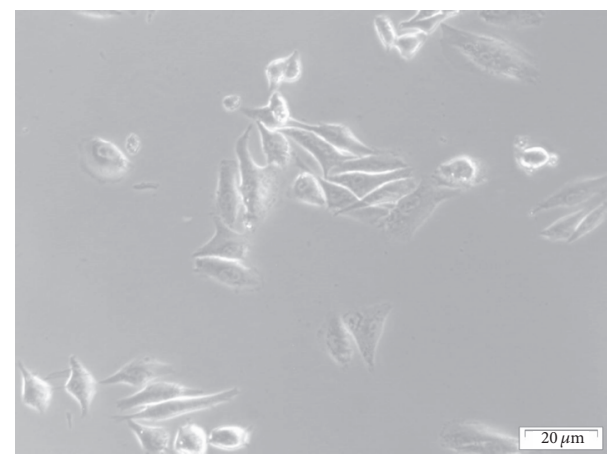

(b)

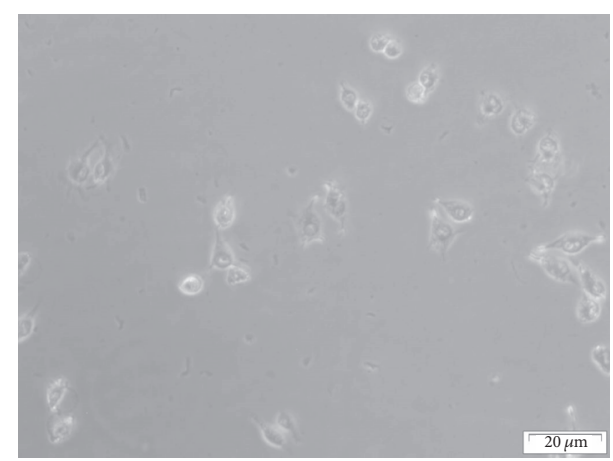

(d)

FIgURE 1: Morphological features of A375 treatment with laser irradiation at $5 \mathrm{~J} / \mathrm{cm}^{2}$ or combination of laser and PS (2.5 $\left.\mu \mathrm{M}\right)$. (a) Laser irradiation alone at $682 \mathrm{~nm}$; (b) laser irradiation alone at $594 \mathrm{~nm}$; (c) combination of laser irradiation at $682 \mathrm{~nm}$ and $2.5 \mu \mathrm{M} \mathrm{AlPcS} 4 \mathrm{Cl}$; (d) combination of laser irradiation at $594 \mathrm{~nm}$ and $2.5 \mu \mathrm{M}$ Hyp. Combination of laser and PS ( $\mathrm{AlPcS}_{4} \mathrm{Cl}$ or Hyp) leads to destruction of cells.

Binding Buffer (1x) was again added to cell suspension prior to analysis with flow cytometer. All experimental parameters were monitored using appropriate controls.

2.10. Statistical Analysis. Each set of experiments was repeated six times $(n=6)$ using melanoma cell line at passages between 15 and 20, while each biological assay was performed in triplicate. Untreated cells were compared to treated cells using Sigma Plot version 12.0 and the mean, standard deviation, and standard error were determined. Statistical significance between untreated control cells and treated cells is shown in the graphs as ${ }^{*} P<0.05,{ }^{* *} P<0.01$, and ${ }^{* * *} P<0.001$. Significant differences were considered at the 95th percentile.

\section{Results}

3.1. Changes in Cell Morphology. Photochemical effects of Hyp-PDT and $\mathrm{AlPcS}_{4} \mathrm{Cl}-\mathrm{PDT}$ for treatment of A375 cells in vitro lead to distinctive cell morphological changes and cell death. Cells irradiated with laser dose of $5 \mathrm{~J} / \mathrm{cm}^{2}$ at wavelengths 594 and $682 \mathrm{~nm}$ showed no signs of morphological damage. Figure 1 illustrates morphological features of A375 cells after treatment with laser irradiation at $5 \mathrm{~J} / \mathrm{cm}^{2}$ or combination of cells treated with PS $(2.5 \mu \mathrm{M})$ and incubated for $24 \mathrm{hrs}$, followed by laser irradiation at $594 \mathrm{~nm}$ or $682 \mathrm{~nm}$.
Laser irradiation alone at $682 \mathrm{~nm}$ or $594 \mathrm{~nm}$ did not note any significant morphological changes. However, significant changes in cell morphology were observed when cells previously incubated with $2.5 \mu \mathrm{M} \mathrm{AlPcS}{ }_{4} \mathrm{Cl}$ were irradiated with laser light at $682 \mathrm{~nm}$ (Figure 1(c)) or with $2.5 \mu \mathrm{M}$ Hyp irradiated at $594 \mathrm{~nm}$ (Figure 1(d)). Figures 1(c) and 1(d) indicate that the combination of PS and laser light causes destruction of melanoma in vitro. Signs of cell damage, marked by shrinkage and detachment of A375 cells from the surface of the tissue culture dish, became apparent when A375 cells were incubated with PS for $24 \mathrm{hrs}$ followed by irradiation with laser light.

3.2. Cellular Viability. The cell viability of the A375 cells was assessed by using the Trypan blue dye exclusion viability assay (TB). Trypan blue dye is a negatively charged chromophore that does not interact with intact cell membranes but with damaged cell membranes. Hence, live cells have poor affinity to Trypan blue dye, whereas dead cells have high affinity to Trypan blue. This feature is therefore used to discriminate dead amongst live cells. Untreated cells (cells without PSs and nonirradiated serve as control cells) and treated cells were compared using Trypan blue viability assay $48 \mathrm{hrs}$ after treatment. Percentage cell viability of cells treated with 1 , 2.5 , and $5 \mu \mathrm{M}$ Hyp alone was found to be insignificantly different to untreated cells. However, those treated with 


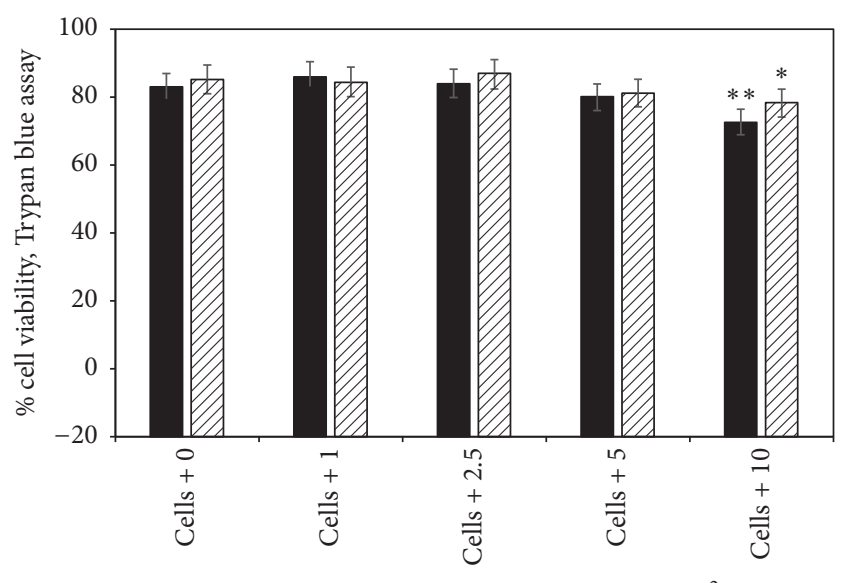

Effect of laser irradiation alone light $\left(\mathrm{J} / \mathrm{cm}^{2}\right)$

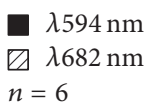

Figure 2: Trypan blue viability assay to evaluate effect of laser irradiation at wavelengths 594 and $682 \mathrm{~nm}$ on A375 cells. Untreated A375 (control: $0 \mathrm{~J} / \mathrm{cm}^{2}$ of laser) were compared with those treated with $1,2.5,5$, and $10 \mathrm{~J} / \mathrm{cm}^{2}$.

$10 \mu \mathrm{M}$ Hyp showed significant differences at all incubation times $(1,4$, and $24 \mathrm{hrs})$. No significant differences were observed between untreated and treated cells with $1,2.5$, 5 , and $10 \mu \mathrm{M} \mathrm{AlPcS}{ }_{4} \mathrm{Cl}$ at all incubation times. The results to show the effect of PSs alone were not presented in this paper but can be made available upon request. In order to evaluate biochemical effects, a concentration of $2.5 \mu \mathrm{M}$ of both PSs, Hyp and AlPcS4Cl, which induce approximately $50 \%$ cytotoxicity (ICD50), was selected.

Laser irradiation of A375 cell alone at 1, 2.5, and $5 \mathrm{~J} / \mathrm{cm}^{2}$ showed no toxicity to A375 cells at both wavelengths (Figure 2). But statistical significant differences between untreated cells and those treated with $10 \mathrm{~J} / \mathrm{cm}^{2}$ at both wavelengths were observed.

Irradiating A375 cells that contained $2.5 \mu \mathrm{M}$ of either Hyp or $\mathrm{AlPcS}_{4} \mathrm{Cl}$ at a wavelength of $594 \mathrm{~nm}$ or $682 \mathrm{~nm}$ with a laser dose of $1,2.5,5$, or $10 \mathrm{~J} / \mathrm{cm}^{2}$, respectively, resulted in a loss of cell viability (Figures 3-5). Comparing the percentage loss of cell viability when A375 were treated with Hyp-PDT versus $\mathrm{AlPcS}_{4} \mathrm{Cl}-\mathrm{PDT}$ at $1 \mathrm{hr}$, the percentage loss was significant at 1 , $2.5,5$, and $10 \mathrm{~J} / \mathrm{cm}^{2}$ when compared to their respective control cell population receiving no irradiation or photosensitizer.

Figure 4 demonstrates the effect of PDT after treating cells with either PS for $4 \mathrm{hrs}$ followed by irradiation at their selective wavelength of absorption. Comparing the percentage loss of cell viability when A375 were treated with Hyp-PDT versus AlPcS4Cl-PDT at 4 hrs, the percentage loss in viability was significantly higher for all fluences when comparing the two PSs, as well as considering the increased incubation periods.

Finally, as expected, cellular viability was severely affected in cells that were incubated with PSs for $24 \mathrm{hrs}$ (Figure 5) as compared to $1 \mathrm{hr}$ and $4 \mathrm{hrs}$ incubation times, suggesting that

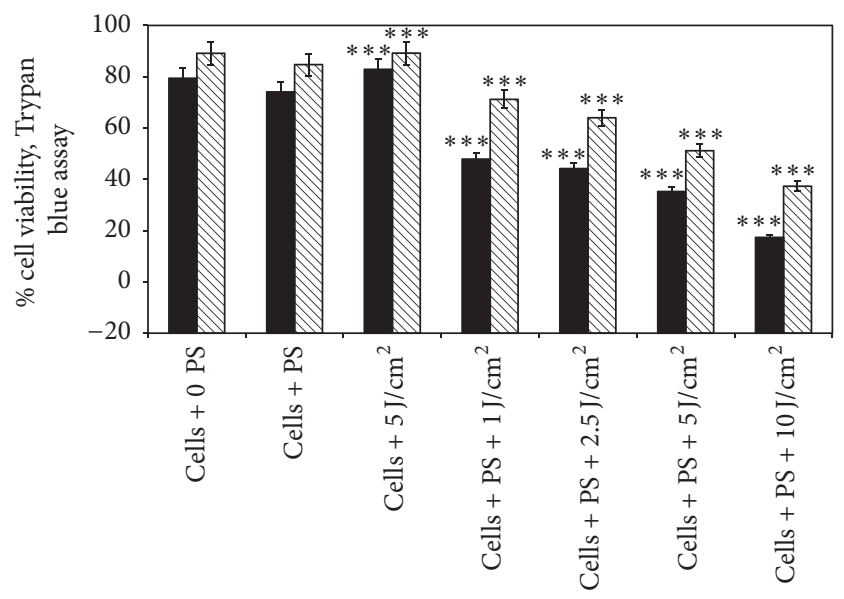

Effect of combination of PS and laser light, $1 \mathrm{hr}$

$$
\begin{aligned}
& \square \text { Hyp } \\
& \mathbb{A} \text { AlPcS4Cl } \\
& n=6
\end{aligned}
$$

FIGURE 3: Trypan blue viability assay to assess the effect of Hyp-PDT versus $\mathrm{AlPcS}_{4} \mathrm{Cl}-\mathrm{PDT}$ when cells were treated with $\mathrm{Hyp}$ or $\mathrm{AlPcS}_{4} \mathrm{Cl}$ for $1 \mathrm{hr}$ followed by laser irradiation at wavelengths 594 and $682 \mathrm{~nm}$, respectively. Untreated A375 (cell + 0 PS, $0 \mathrm{LI}$ ) were compared with those treated with $2.5 \mu \mathrm{M}$ PS, $5 \mathrm{~J} / \mathrm{cm}^{2}$ and those treated with $2.5 \mu \mathrm{M}$ PS $+1,2.5,5$, and $10 \mathrm{~J} / \mathrm{cm}^{2}$.

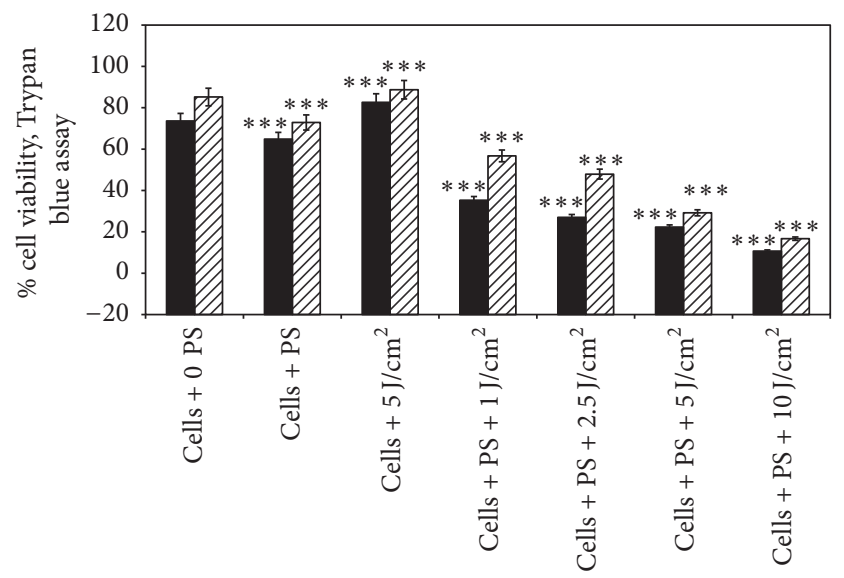

Effect of combination of PS and laser light, $4 \mathrm{hr}$

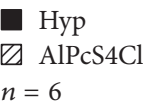

FIgure 4: Trypan blue viability assay to assess the effect of HypPDT versus $\mathrm{AlPcS}_{4}$ Cl-PDT when cells were treated with Hyp or $\mathrm{AlPcS}_{4} \mathrm{Cl}$ for $4 \mathrm{hrs}$ followed by laser irradiation at wavelengths 594 and $682 \mathrm{~nm}$, respectively. Untreated A375 (cell +0 PS, $0 \mathrm{LI}$ ) were compared with those treated with $2.5 \mu \mathrm{M} \mathrm{PS}, 5 \mathrm{~J} / \mathrm{cm}^{2}$, and those treated with $2.5 \mu \mathrm{M}$ PS $+1,2.5,5$, and $10 \mathrm{~J} / \mathrm{cm}^{2}$.

the longer the incubation period of cells with both PSs, the higher the PDT effect.

3.3. Cytotoxicity. Incubation of A375 cells with Hyp at 1, 2.5, and $5 \mu \mathrm{M}$ exhibited no significance difference on the LDH signal between control cells and treated cells. However, at 


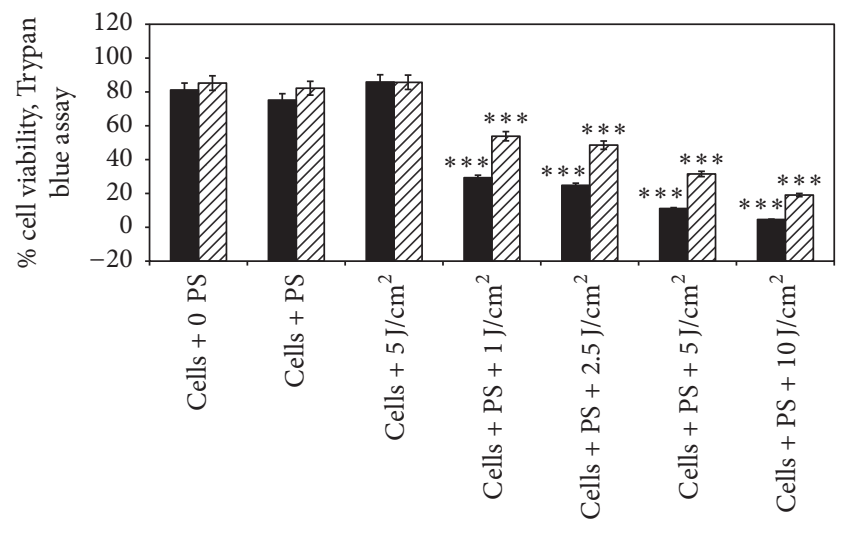

Effect of combination of PS and lasr light, 24 hrs

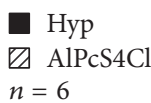

Figure 5: Trypan blue viability assay to assess the effect of HypPDT versus $\mathrm{AlPcS}_{4}$ Cl-PDT when cells were treated with Hyp or $\mathrm{AlPcS}_{4} \mathrm{Cl}$ for $24 \mathrm{hrs}$ followed by laser irradiation at wavelengths 594 and $682 \mathrm{~nm}$, respectively. Untreated A375 (cell +0 PS, 0 LI) were compared with those treated with $2.5 \mu \mathrm{M}$ PS, $5 \mathrm{~J} / \mathrm{cm}^{2}$ and those treated with $2.5 \mu \mathrm{MPS}+1,2.5,5$, and $10 \mathrm{~J} / \mathrm{cm}^{2}$.

$10 \mu \mathrm{M}$, alone statistical differences within both control and treated cells were observed, suggesting that $10 \mu \mathrm{M}$ Hyp alone is toxic to cells. No statistical significant differences were observed in the LDH signal between untreated and treated cells with $1,2.5,5$, and $10 \mu \mathrm{M} \mathrm{AlPcS}{ }_{4} \mathrm{Cl}$ at all incubation times. Laser irradiation of A375 cell alone at 1, 2.5, and $5 \mathrm{~J} / \mathrm{cm}^{2}$ showed no toxicity to A375 cells at either wavelengths (Table 2). However, statistical significant differences between untreated cells and those treated with $10 \mathrm{~J} / \mathrm{cm}^{2}$ at $682 \mathrm{~nm}$ laser $(P<0.05)$ were noted. No significant differences between untreated cells and those treated with $10 \mathrm{~J} / \mathrm{cm}^{2}$ at $594 \mathrm{~nm}$ laser were noted.

Susceptibility of cells to Hyp-PDT and $\mathrm{AlPcS}_{4} \mathrm{Cl}-\mathrm{PDT}$ treatment was evaluated over a 1,4 , and $24 \mathrm{hrs}$ period. $\mathrm{LDH}$ signal is inversely proportional to viable cell number with intact membrane integrity in culture. Loss of membrane integrity in cells was confirmed when difference in $\mathrm{LDH}$ signal of untreated and treated groups was statistically significant. Significant cellular damage was noted in treated cells compared to untreated cells (Table 3 ).

3.4. Cell Proliferation. The CellTiter-Glo Luminescent Cell Proliferation Assay is a robust, homogeneous, fast, and sensitive assay based on quantification of the content of ATP in cells to signal the number of metabolically energetic cells. It involves mixing a single reagent with cells in culture media to lyse cells and generating the luminescent signal that is a measure of the ATP content present in cells. A375 ATP content was evaluated to determine the level of metabolic active versus metabolically damaged cells after PDT treatment. ATP is a marker for both viability and proliferation of cells. ATP signal is directly proportional to the number of metabolically active cells.
The amount of ATP was found higher in laser-treated cells. Cells incubated with PSs at $2.5 \mu \mathrm{M}$ and those treated with $5 \mathrm{~J} / \mathrm{cm}^{2}$ alone did not result in significant loss of metabolically active cells. However, exposure of A375 cells to Hyp-PDT and $\mathrm{AlPcS}_{4} \mathrm{Cl}-\mathrm{PDT}$ resulted in a decreased ATP signal. The decrease in ATP content of cells was laser dosedependent (Figures 6, 7, and 8). The A375 cells after PDT treatment displayed significant changes in cell proliferation as compared to untreated cells.

When comparing the reduction in proliferation between the control and Hyp-PDT at different fluences, it varies in efficiency in reducing cellular activity compared to $\mathrm{AlPcS}_{4} \mathrm{Cl}$ PDT although the time of exposure also influences the effectiveness of the photosensitizers.

In addition, when comparing each photosensitizer at increasing fluences to their controls receiving no photosensitizer or irradiation, there was in most cases a statistically significant decrease in cellular proliferation as indicated in the figures.

Of particular interest is to note that the time of incubation of cells with respective photosensitizer directly influenced the proliferation as expressed by ATP content. The longer the incubation time prior to irradiation, namely, 1, 4, and $24 \mathrm{hrs}$, the greater the decrease in proliferation. This may be directly related to the uptake and positioning of the photosensitizer within the cell and cellular organelles.

Within all three methods used in this study, TB, LDH, and ATP, the decreased viability, membrane integrity, and proliferation of cells were inversely proportional to the concentration of Hyp, $\mathrm{AlPcS}_{4} \mathrm{Cl}$, and laser dose alone or combined. The higher the concentration of PSs or laser dose the higher the loss of cell viability, membrane integrity, and proliferation of cells.

3.5. Mode of Cell Death. The Annexin V FITC apoptosis detection kit was used to evaluate the mode of cell death after Hyp-PDT and $\mathrm{AlPcS}_{4} \mathrm{Cl}-\mathrm{PDT}$ treatment. Untreated cells were compared to PS-treated, laser-treated, and PDT-treated cells using flow cytometry.

A375 cells treated with $2.5 \mu \mathrm{M}$ Hyp; $2.5 \mu \mathrm{M} \mathrm{AlPcS} \mathrm{Cl}_{4}$; $5 \mathrm{~J} / \mathrm{cm}^{2}$ laser at $594 \mathrm{~nm}$ and laser irradiation at $682 \mathrm{~nm}$ displayed no significant variations in percentage viability compared to the control group. Hyp-PDT treatment resulted in a significant number of apoptotic cells, $24.5 \%$ late apoptosis and $20.6 \%$ early apoptotic cell death after 4 hrs PDT treatment and $45.1 \%$ of late apoptotic cell death and $28.3 \%$ early apoptotic cell death after $24 \mathrm{hrs}$ PDT treatment. $\mathrm{AlPcS}_{4} \mathrm{Cl}$ PDT treatment caused $14.3 \%$ late apoptosis and 3.1\% early apoptotic and $1.2 \%$ necrotic cell death mode after $4 \mathrm{hrs}$ PDT treatment and $18.2 \%$ of late apoptotic, $3.4 \%$ early apoptotic, and 3.9\% necrotic cell death mode after 24 hrs PDT treatment. Table 4 indicates the differences between HypPDT and AlPcS4Cl-PDT cell populations as percentages of live, necrotic, early apoptotic, and late apoptotic cells. These results are in agreement with the results presented in $\mathrm{TB}$, $\mathrm{LDH}$, and ATP that indicate that duration of incubation time of cells with PS is directly related to increased levels of cell damage and death. 


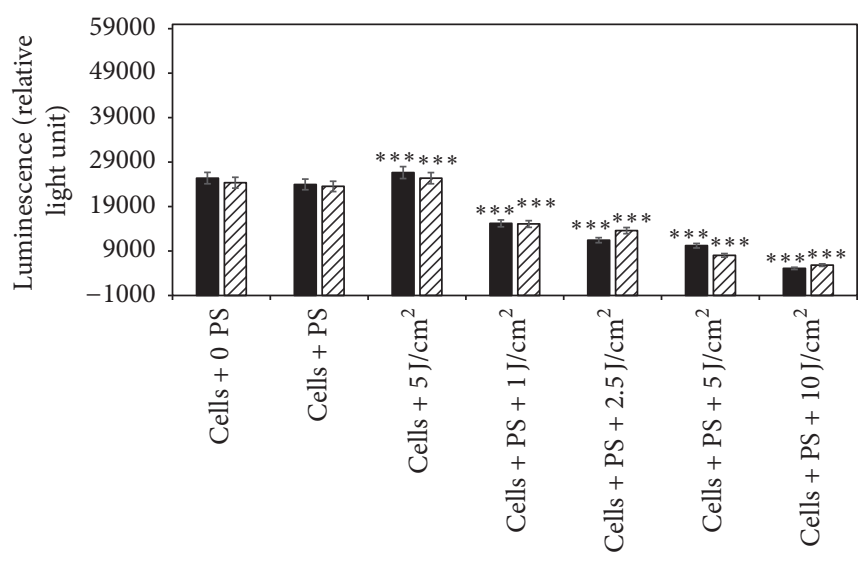

Effect of combination of PS and laser light, $1 \mathrm{hr}$

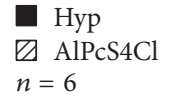

Figure 6: Adenosine triphosphate assay to assess the effect of Hyp-PDT versus $\mathrm{AlPcS}_{4} \mathrm{Cl}-\mathrm{PDT}$ when cells were treated with $\mathrm{Hyp}$ or AlPcS $\mathrm{Cl}$ for $1 \mathrm{hr}$ followed by laser irradiation at wavelengths 594 and $682 \mathrm{~nm}$, respectively. Untreated A375 (cell + 0 PS, 0 LI) were compared with those treated with $2.5 \mu \mathrm{M}$ PS, $5 \mathrm{~J} / \mathrm{cm}^{2}$ and those treated with $2.5 \mu \mathrm{M}$ PS $+1,2.5,5$, and $10 \mathrm{~J} / \mathrm{cm}^{2}$.

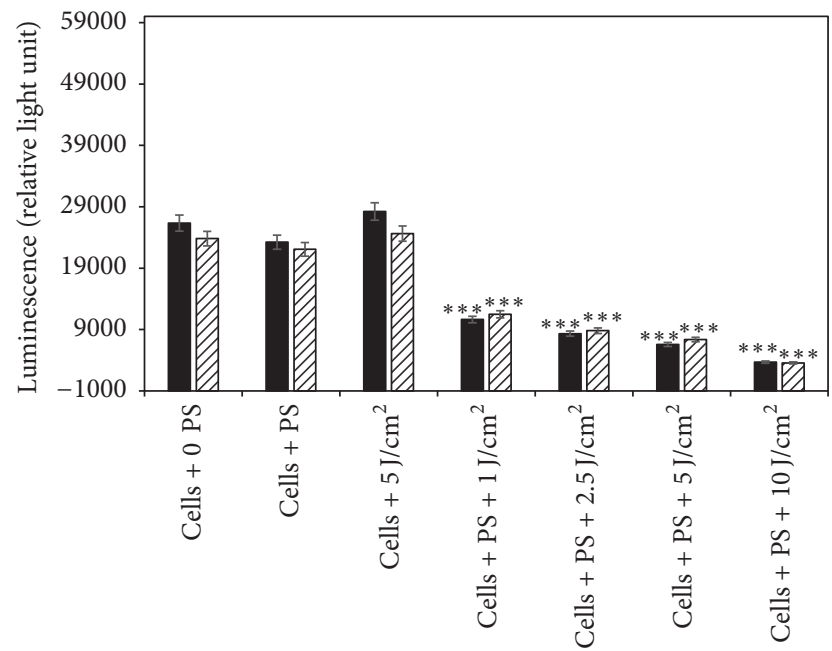

Effect of combination of PS and laser light, $4 \mathrm{hrs}$

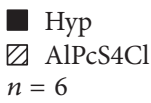

FIGURE 7: Adenosine triphosphate assay to assess the effect of Hyp-PDT versus $\mathrm{AlPcS}_{4} \mathrm{Cl}-\mathrm{PDT}$ when cells treated with Hyp or $\mathrm{AlPcS}_{4} \mathrm{Cl}$ for $4 \mathrm{hrs}$ followed by laser irradiation at wavelengths 594 and $682 \mathrm{~nm}$, respectively. Untreated A375 (cell +0 PS, 0 LI) were compared with those treated with $2.5 \mu \mathrm{M}$ PS, $5 \mathrm{~J} / \mathrm{cm}^{2}$ and those treated with $2.5 \mu \mathrm{MPS}+1,2.5,5$, and $10 \mathrm{~J} / \mathrm{cm}^{2}$.

Overall it was noted that cells incubated with photosensitizers did not inflict significant cellular damage until irradiated. Upon irradiation, PDT, both $\mathrm{Hyp}$ and $\mathrm{AlPcS}_{4} \mathrm{Cl}$ induce early apoptosis. It is notable that Hyp also cause a significant amount of late apoptotic cells while the main mode

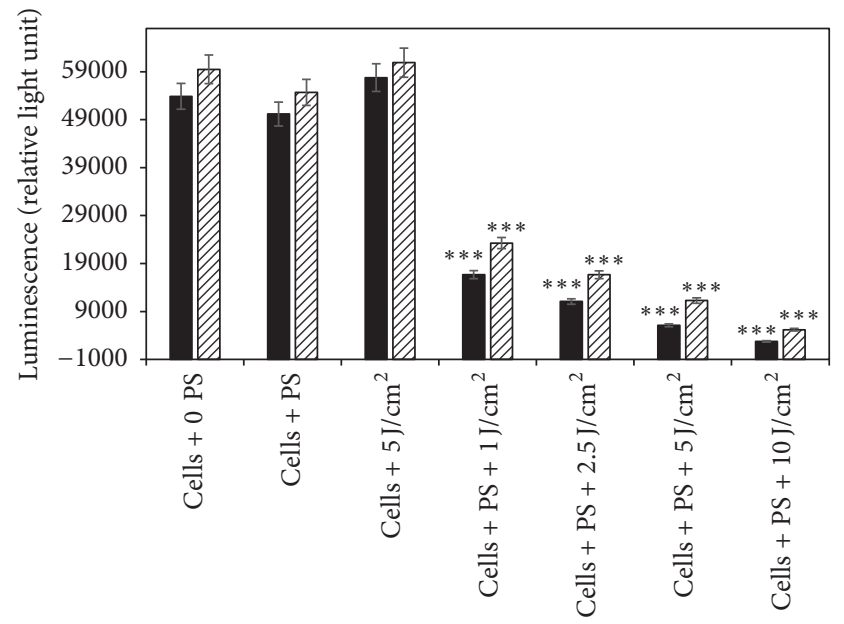

Effect of combination of PS and laser light, $24 \mathrm{hrs}$

$$
\begin{aligned}
& \square \text { Hyp } \\
& \square \text { AlPcS4Cl } \\
& n=6
\end{aligned}
$$

FIGURE 8: Adenosine triphosphate assay to assess the effect of HypPDT versus $\mathrm{AlPcS}_{4}$ Cl-PDT when cells were treated with Hyp or $\mathrm{AlPcS}_{4} \mathrm{Cl}$ for $24 \mathrm{hrs}$ followed by laser irradiation at wavelengths 594 and $682 \mathrm{~nm}$, respectively. Untreated A375 (cell + 0 PS, 0 LI) were compared with those treated with $2.5 \mu \mathrm{M}$ PS, $5 \mathrm{~J} / \mathrm{cm}^{2}$ and those treated with $2.5 \mu \mathrm{M}$ PS $+1,2.5,5$, and $10 \mathrm{~J} / \mathrm{cm}^{2}$.

of cell death induced by $\mathrm{AlPcS}_{4} \mathrm{Cl}$ is early apoptosis. Additionally, the incubation period of cells with photosensitizer after irradiation of 4 and $24 \mathrm{hrs}$ influences the percentage of cell death induced in an increasing time-dependent manner.

Irrespective of incubation times, mode of cell death in A375 cells from both Hyp-PDT and $\mathrm{AlPcS}_{4} \mathrm{ClPDT}$ was 
TABLE 2: LDH membrane integrity assay to evaluate effect of laser irradiation at 682 and $594 \mathrm{~nm}$ on A375 cells.

\begin{tabular}{|c|c|c|c|c|c|}
\hline Laser irradiation & Cells $+0 \mathrm{~J} / \mathrm{cm}^{2}$ & Cells $+1 \mathrm{~J} / \mathrm{cm}^{2}$ & Cells $+2.5 \mathrm{~J} / \mathrm{cm}^{2}$ & Cells $+5 \mathrm{~J} / \mathrm{cm}^{2}$ & Cells $+10 \mathrm{~J} / \mathrm{cm}^{2}$ \\
\hline$\lambda 682$ & $0.490 \pm 0.046^{\mathrm{a}}$ & $0.474 \pm 0.047$ & $0.535 \pm 0.050$ & $0.540 \pm 0.061$ & $0.617 \pm 0.095^{*}$ \\
\hline$\lambda 594$ & $0.505 \pm 0.047$ & $0.536 \pm 0.052$ & $0.544 \pm 0.046$ & $0.547 \pm 0.046$ & $0.676 \pm 0.079$ \\
\hline
\end{tabular}

$n=6$; LDH: Lactate Dehydrogenase; ${ }^{*} P<0.05 ;{ }^{\mathrm{a}} \pm$ SE.

TABLE 3: LDH membrane integrity assay to evaluate PDT effect of Hyp and $\mathrm{AlPcS}_{4} \mathrm{Cl}$.

\begin{tabular}{|c|c|c|c|c|c|c|c|}
\hline & $\begin{array}{c}\text { Cells + no PS } \\
\text { no LI }\end{array}$ & $\begin{array}{c}\text { Cells + } \\
2,5 \mu \mathrm{M} \text { PS }\end{array}$ & $\begin{array}{l}\text { Cells + } \\
5 \mathrm{~J} / \mathrm{cm}^{2}\end{array}$ & $\begin{array}{c}\text { Cells + } \\
2,5 \mu \mathrm{M} \mathrm{PS}+ \\
1 \mathrm{~J} / \mathrm{cm}^{2}\end{array}$ & $\begin{array}{c}\text { Cells }+ \\
2,5 \mu \mathrm{M} \mathrm{PS} \\
+2.5 \mathrm{~J} / \mathrm{cm}^{2} \\
\end{array}$ & $\begin{array}{c}\text { Cells + } \\
2,5 \mu \mathrm{M} \mathrm{PS}+ \\
5 \mathrm{~J} / \mathrm{cm}^{2}\end{array}$ & $\begin{array}{c}\text { Cells }+ \\
2,5 \mu \mathrm{M} \text { PS } \\
+10 \mathrm{~J} / \mathrm{cm}^{2} \\
\end{array}$ \\
\hline \multicolumn{8}{|c|}{$\mathrm{AlPcS}_{4} \mathrm{Cl}$} \\
\hline $1 \mathrm{hr}$ & $\begin{array}{c}0.460 \\
\pm 0.039^{\mathrm{a}}\end{array}$ & $\begin{array}{c}0.470 \\
\pm 0.026\end{array}$ & $\begin{array}{c}0.386 \\
\pm 0.026\end{array}$ & $\begin{array}{c}0.485 \\
\pm 0.031\end{array}$ & $\begin{array}{c}0.494 \\
\pm 0.024\end{array}$ & $\begin{array}{c}0.492 \\
\pm 0.029\end{array}$ & $\begin{array}{c}0.507 \\
\pm 0.031\end{array}$ \\
\hline $4 \mathrm{hrs}$ & $\begin{array}{c}0.476 \\
\pm 0.016\end{array}$ & $\begin{array}{c}0.489 \\
\pm 0.014\end{array}$ & $\begin{array}{c}0.445 \\
\pm 0.026\end{array}$ & $\begin{array}{c}0.500 \\
\pm 0.014\end{array}$ & $\begin{array}{c}0.525 \\
\pm 0.016\end{array}$ & $\begin{array}{c}0.545 \\
\pm 0.020^{* *}\end{array}$ & $\begin{array}{c}0.534 \\
\pm 0.028^{* *}\end{array}$ \\
\hline $24 \mathrm{hrs}$ & $\begin{array}{c}0.407 \\
\pm 0.018 \\
\end{array}$ & $\begin{array}{c}0.448 \\
\pm 0.014 \\
\end{array}$ & $\begin{array}{c}0.360 \\
\pm 0.017 \\
\end{array}$ & $\begin{aligned} & 0.412 \\
& \pm 0.024^{* *} \\
&\end{aligned}$ & $\begin{aligned} & 0.515 \\
& \pm 0.035^{* *} \\
&\end{aligned}$ & $\begin{aligned} & 0.524 \\
& \pm 0.036^{* *} \\
&\end{aligned}$ & $\begin{array}{c}0.535 \\
\pm 0.036^{* *} \\
\end{array}$ \\
\hline \multicolumn{8}{|c|}{ Hyp } \\
\hline $1 \mathrm{hrs}$ & $\begin{array}{c}0.453 \\
\pm 0.017\end{array}$ & $\begin{array}{c}0.467 \\
\pm 0.017\end{array}$ & $\begin{array}{c}0.428 \\
\pm 0.020\end{array}$ & $\begin{array}{c}0.475 \\
\pm 0.017\end{array}$ & $\begin{array}{c}0.482 \\
\pm 0.016\end{array}$ & $\begin{array}{c}0.495 \\
\pm 0.018\end{array}$ & $\begin{array}{c}0.562 \\
\pm 0.045^{*}\end{array}$ \\
\hline $4 \mathrm{hrs}$ & $\begin{array}{c}0.431 \\
\pm 0.012\end{array}$ & $\begin{array}{c}0.445 \\
\pm 0.011\end{array}$ & $\begin{array}{c}0.403 \\
\pm 0.018\end{array}$ & $\begin{array}{c}0.461 \\
\pm 0.013\end{array}$ & $\begin{array}{c}0.471 \\
\pm 0.013^{* *}\end{array}$ & $\begin{array}{c}0.527 \\
\pm 0.033^{* *}\end{array}$ & $\begin{array}{c}0.539 \\
\pm 0.035^{* *}\end{array}$ \\
\hline $24 \mathrm{hrs}$ & $\begin{array}{c}0.450 \\
\pm 0.006\end{array}$ & $\begin{array}{c}0.480 \\
\pm 0.009^{*}\end{array}$ & $\begin{array}{c}0.438 \\
\pm 0.009\end{array}$ & $\begin{array}{c}0.496 \\
\pm 0.010^{* *}\end{array}$ & $\begin{array}{c}0.500 \\
\pm 0.011^{* *} \\
\end{array}$ & $\begin{array}{c}0.527 \\
\pm 0.010^{* *} \\
\end{array}$ & $\begin{array}{c}0.566 \\
\pm 0.030^{* *} \\
\end{array}$ \\
\hline
\end{tabular}

$n=6$; LDH: Lactate Dehydrogenase; LI: laser irradiation; PS: photosensitizer; ${ }^{*} P<0.05 ;{ }^{* *} P<0.01 ;{ }^{\mathrm{a}} \pm \mathrm{SE}$.

TABLE 4: The Annexin V FITC apoptosis detection kit was performed to evaluate mode of cell death on A375 cells after treatment with Hyp-PDT or $\mathrm{AlPcS}_{4} \mathrm{Cl}-\mathrm{PDT}$.

\begin{tabular}{|c|c|c|c|c|}
\hline \multirow{2}{*}{ Variable } & \multicolumn{4}{|c|}{ Mode of cell death } \\
\hline & Live cells (\%) & Necrotic cells (\%) & Early apoptotic cells (\%) & Late apoptotic cells (\%) \\
\hline \multicolumn{5}{|c|}{ Hyp } \\
\hline Cells only & 100 & 0 & 0 & 0 \\
\hline Cells $+5 \mathrm{~J} / \mathrm{cm}^{2}$ at $594 \mathrm{~nm}$ & 92.7 & 2 & 2.7 & 2.6 \\
\hline Cell + Hyp $(2.5 \mu \mathrm{M})$ & 93.7 & 0.4 & 4.2 & 1.7 \\
\hline Cells + PDT 4 hrs & 53.5 & 1.4 & 24.5 & 20.6 \\
\hline Cells + PDT 24 hrs & 25 & 1.6 & 45.1 & 28.3 \\
\hline \multicolumn{5}{|c|}{$\mathrm{AlPcS}_{4} \mathrm{Cl}$} \\
\hline Cells only & 100 & 0 & 0 & 0 \\
\hline Cells $+5 \mathrm{~J} / \mathrm{cm}^{2}$ at $682 \mathrm{~nm}$ & 92.7 & 1.5 & 3.1 & 2.7 \\
\hline Cells $+\mathrm{AlPcS}_{4} \mathrm{Cl}(2.5 \mu \mathrm{M})$ & 87.5 & 0.4 & 9.9 & 2.2 \\
\hline Cells + PDT 4 hrs & 81.3 & 1.2 & 14.3 & 3.1 \\
\hline Cells + PDT 24 hrs & 74.5 & 3.9 & 18.2 & 3.4 \\
\hline
\end{tabular}

induced as early apoptosis. Although with Hyp-PDT a significant percentage of cells was observed in the late apoptotic phase as well. Apoptosis is a complex process that involves many pathways regulated by specific proteases called caspases. Activation of caspase 3 and a collapse in plasma membrane integrity are main indicators of early apoptosis whereas late apoptosis is characterized by nuclear fragmentation. Our future work will confirm these findings by in-depth genetic expression studies.

\section{Discussion}

PDT for treatment of skin cancer has a series of inherent advantageous properties over chemotherapy and radiotherapy based on the fact that they destroy diseased tissue while 
leaving normal tissue unharmed. PDT is the product of a reaction of a tumor localizing PS and light $[20,21]$. The efficiency of PDT, however, depends on characteristics of the PS, wavelength of light to activate the PS, and molecular oxygen [22]. The results obtained from cell viability and cytotoxicity studies of treated A375 cells indicated that $2.5 \mu \mathrm{M}$ of both Hyp and $\mathrm{AlPcS}_{4} \mathrm{Cl}$ caused an approximately 50\% decrease in cell viability and therefore was chosen as the optimal concentration of PSs for use in phototoxicity experiments to determine the optimal PDT treatment of melanoma in vitro.

The continuous wave diode lasers at wavelengths $594 \mathrm{~nm}$ and $682 \mathrm{~nm}$ were chosen to irradiate A375 cells in absence or presence of Hyp and $\mathrm{AlPcS}_{4} \mathrm{Cl}$, respectively. Irradiating cells only with both lasers at $1,2,5$, and $5 \mathrm{~J} / \mathrm{cm}^{2}$ was found nontoxic to cells. However, using TB and $\mathrm{LDH}$ assays, contradictory results were obtained in terms of treatment with $10 \mathrm{~J} / \mathrm{cm}^{2}$ at both wavelengths. With $\mathrm{LDH}$ method, only $10 \mathrm{~J} / \mathrm{cm}^{2}$ of laser irradiation at $682 \mathrm{~nm}$ showed a slight damage of cell membrane to A375 cells (Table 2), as compared to results in TB method that a significant decrease in cell viability was obtained at $10 \mathrm{~J} / \mathrm{cm}^{2}$ (Figure 2). Hadjur et al., in 1996, demonstrated for the first time that photoactivated Hyp under aerobic conditions is toxic to human amelanotic cells than in pigmented melanoma, while aluminium disulphonated phthalocyanine has been shown to have potential for the PDT treatment of skin melanoma cancer [13, 23]. Phototoxicity measurements in this study showed that A375 cells are susceptible to photoactivated $\mathrm{Hyp}$ and $\mathrm{AlPcS}_{4} \mathrm{Cl}$; however, to a larger degree, cells were already affected by photoactivated Hyp from as early as one hour after cells were incubated with Hyp followed by irradiation at $594 \mathrm{~nm}$ (Figure 3). The viability of A375 cells decreased with the increase in PS concentration at every incubation period. The incubation of cells for $24 \mathrm{hrs}$ with Hyp, followed by irradiation with corresponding laser doses, was lethal to A375 cells (Figure 8).

It is well known that the efficiency of PDT depends on the internalization of PSs in cells. The nucleus, plasma membranes, mitochondria, and lysosomes have been identified as targets for PS localization [24]. Hypericin localizes predominantly in intracellular membranes such as ER and Golgi apparatus and under different treatment conditions in the mitochondrial and nuclear membrane, as well as in lysosomes $[19,25]$. On the other hand, $\mathrm{AlPcS}_{4} \mathrm{Cl}$ has been previously been shown to localize in mitochondria and lysosomes of melanoma cells in vitro $[16,17]$. Studies by Castano et al., 2005, showed that PSs which localize in mitochondria induce cell damage via apoptosis, whereas those that localized in lysosome would generally cause cell damage via necrosis and apoptosis [26].

Davids et al., 2008, reported that exposure of pigmented melanoma and melanocytes to $3 \mu \mathrm{M}$ Hyp activated with UV light induces a necrotic mode of cell death and an apoptotic mode of cell death in nonpigmented melanoma cells and keratinocytes. We demonstrate, in this study, that incubation of A375 cells with Hyp for 24 hrs followed by irradiation with laser at 594 induces apoptotic cell death, whereas incubation of A375 cells with $\mathrm{AlPcS}_{4} \mathrm{Cl}$ for $24 \mathrm{hrs}$ followed by irradiation with $682 \mathrm{~nm}$ laser results in low percentage of apoptotic and necrotic death mode as compared to a higher degree of apoptotic cells in Hyp-PDT-treated cells. Our results are in agreement with previous report that the type of cell death activated by PDT can be influenced by modifying the treatment protocol to lead to a desired apoptosis/necrosis ratio that is advantageous for complete tumor destruction. Additionally, aspects inducing the cell death mode include incubation settings, PS concentration and localization, and light dose [27].

\section{Conclusion}

In conclusion, the results presented in this paper show that photodynamic effect of Hyp and $\mathrm{AlPcS}_{4} \mathrm{Cl}$ combined with laser irradiation in vitro occurs as early as $1 \mathrm{hr}$ after incubating cells with PS, followed by laser irradiation. Irradiation of cells in the presence of Hyp and $\mathrm{AlPcS}_{4} \mathrm{Cl}$, with diode laser at $594 \mathrm{~nm}$ and $682 \mathrm{~nm}$, respectively, induced destruction of A375 cells in a PS concentration and time- and light dosedependent manner. The longer the incubation period of cells with PS, the higher the PDT effect. A375 cells were found to be more susceptible to photoactivated Hyp as compared to $\mathrm{AlPcS}_{4} \mathrm{Cl}$. Hyp is shown to be the hopeful candidate for the desirable PDT destruction of melanoma in vitro. PDT with $\mathrm{Hyp}$ or $\mathrm{AlPcS}_{4} \mathrm{Cl}$ has been shown to successfully induce apoptosis or necrosis in melanoma.

\section{Conflicts of Interest}

The authors declare that there are no conflicts of interest.

\section{Acknowledgments}

This work is based on the research supported by the South African Research Chairs Initiative of the Department of Science and Technology and National Research Foundation of South Africa (Grant no. 98337). The authors sincerely acknowledge the University of Johannesburg, the National Laser Centre, and the National Research Foundation of South Africa (CSIR-DST) for their financial grant support.

\section{References}

[1] R. A. Weinberg, "How cancer arises.," Scientific American, vol. 275, no. 3, pp. 62-70, 1996.

[2] S. Pelengaris and M. Khan, The Molecular Biology of Cancer, Wiley-Blackwell, 2006.

[3] A. R. Rhodes, "Public education and cancer of the skin. What do people need to know about melanoma and nonmelanoma skin cancer?" Cancer, vol. 75, no. 2 S, pp. 613-636, 1995.

[4] B. K. Armstrong and A. Kricker, "The epidemiology of UV induced skin cancer," Journal of Photochemistry and Photobiology B: Biology, vol. 63, no. 1-3, pp. 8-18, 2001.

[5] R. N. Saladi and A. N. Persaud, "The causes of skin cancer: a comprehensive review," Drugs of Today, vol. 41, no. 1, pp. 37-53, 2005.

[6] T. Kim, R. N. Amaria, C. Spencer, A. Reuben, Z. A. Cooper, and J. A. Wargo, "Combining targeted therapy and immune checkpoint inhibitors in the treatment of metastatic melanoma," Cancer Biology and Medicine, vol. 11, no. 4, pp. 237-246, 2014. 
[7] M. Zigler, G. J. Villares, D. C. Lev, V. O. Melnikova, and M. Bar-Eli, "Tumor immunotherapy in melanoma: Strategies for overcoming mechanisms of resistance and escape," American Journal of Clinical Dermatology, vol. 9, no. 5, pp. 307-311, 2008.

[8] M. T. Wan and J. Y. Lin, "Current evidence and applications of photodynamic therapy in dermatology," Clinical, Cosmetic and Investigational Dermatology, vol. 7, pp. 145-163, 2014.

[9] A. E. O'Connor, W. M. Gallagher, and A. T. Byrne, "Porphyrin and nonporphyrin photosensitizers in oncology: preclinical and clinical advances in photodynamic therapy," Photochemistry and Photobiology, vol. 85, no. 5, pp. 1053-1074, 2009.

[10] N. Jain, V. Bhardwaj, and S. Yadav, "Photosensitizer: Role in Therapy," Archives of Applied Science Research, vol. 2, pp. 196206, 2010

[11] M. H. Gold, Photodynamic Therapy in Dermatology, Springer, New York, NY, USA, 2011.

[12] W. Laffers, A.-C. Busse, J. Mahrt et al., "Photosensitizing effects of hypericin on head neck squamous cell carcinoma in vitro," European Archives of Otorhinolaryngology, vol. 272, no. 3, pp. 711-718, 2015.

[13] H. Kolarova, P. Nevrelova, R. Bajgar, D. Jirova, K. Kejlova, and M. Strnad, "In vitro photodynamic therapy on melanoma cell lines with phthalocyanine," Toxicology in Vitro, vol. 21, no. 2, pp. 249-253, 2007.

[14] L. M. Davids, B. Kleemann, D. Kacerovská, K. Pizinger, and S. H. Kidson, "Hypericin phototoxicity induces different modes of cell death in melanoma and human skin cells," Journal of Photochemistry and Photobiology B: Biology, vol. 91, no. 2-3, pp. 67-76, 2008.

[15] N. Sekkat, H. Van Den Bergh, T. Nyokong, and N. Lange, "Like a bolt from the blue: Phthalocyanines in biomedical optics," Molecules, vol. 17, no. 1, pp. 98-144, 2012.

[16] Q. Peng, G. W. Farrants, K. Madslien et al., "Subcellular localization, redistribution and photobleaching of sulfonated aluminum phthalocyanines in a human melanoma cell line," International Journal of Cancer, vol. 49, no. 2, pp. 290-295, 1991.

[17] I. Ndhundhuma, C. Hauser, C. Scalfi-Happ, A. Rück, and R. Steiner, "Subcellular co-localization of aluminum (III) phthalocyanine chloride tetrasulphonate with fluorescent markers in the human melanoma cell-line HT-144," Medical Laser Application, vol. 26, no. 3, pp. 93-100, 2011.

[18] P. S. Chung, C. K. Rhee, K. H. Kim et al., "Intratumoral hypericin and KTP laser therapy for transplanted squamous cell carcinoma," Laryngoscope, vol. 110, no. 8, pp. 1312-1316, 2000.

[19] P. Agostinis, A. Vantieghem, W. Merlevede, and P. A. M. De Witte, "Hypericin in cancer treatment: More light on the way," International Journal of Biochemistry and Cell Biology, vol. 34, no. 3, pp. 221-241, 2002.

[20] W. M. Sharman, C. M. Allen, and J. E. Van Lier, "Photodynamic therapeutics: basic principles and clinical applications," Drug Discovery Today, vol. 4, no. 11, pp. 507-517, 1999.

[21] K. Kalka, N. Ahmad, T. Criswell, D. Boothman, and H. Mukhtar, "Up-regulation of clusterin during phthalocyanine 4 photodynamic therapy-mediated apoptosis of tumor cells and ablation of mouse skin tumors," Cancer Research, vol. 60, no. 21, pp. 5984-5987, 2000.

[22] C. Hadjur, M.-J. Richard, M.-O. Parat, P. Jardon, and A. Favier, "Photodynamic effects of hypericin on lipid peroxidation and antioxidant status in melanoma cells," Photochemistry and Photobiology, vol. 64, no. 2, pp. 375-381, 1996.
[23] N. L. Oleinick and H. H. Evans, "The photobiology of photodynamic therapy: cellular targets and mechanisms," Radiation Research, vol. 150, no. 5, pp. S146-S156, 1998.

[24] A. P. Castano, T. N. Demidova, and M. R. Hamblin, "Mechanisms in photodynamic therapy: part one-photosensitizers, photochemistry and cellular localization," Photodiagnosis and Photodynamic Therapy, vol. 1, no. 4, pp. 279-293, 2004.

[25] R. Sanovic, B. Krammer, S. Grumboeck, and T. Verwanger, "Time-resolved gene expression profiling of human squamous cell carcinoma cells during the apoptosis process induced by photodynamic treatment with hypericin," International Journal of Oncology, vol. 35, no. 4, pp. 921-939, 2009.

[26] A. P. Castano, T. N. Demidova, and M. R. Hamblin, "Mechanisms in photodynamic therapy: part two-cellular signaling, cell metabolism and modes of cell death," Photodiagnosis and Photodynamic Therapy, vol. 2, no. 1, pp. 1-23, 2005.

[27] P. Mroz, A. Yaroslavsky, G. B. Kharkwal, and M. R. Hamblin, "Cell death pathways in photodynamic therapy of cancer," Cancers, vol. 3, no. 2, pp. 2516-2539, 2011. 


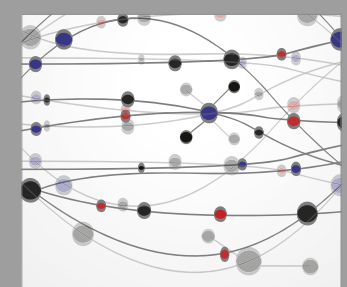

The Scientific World Journal
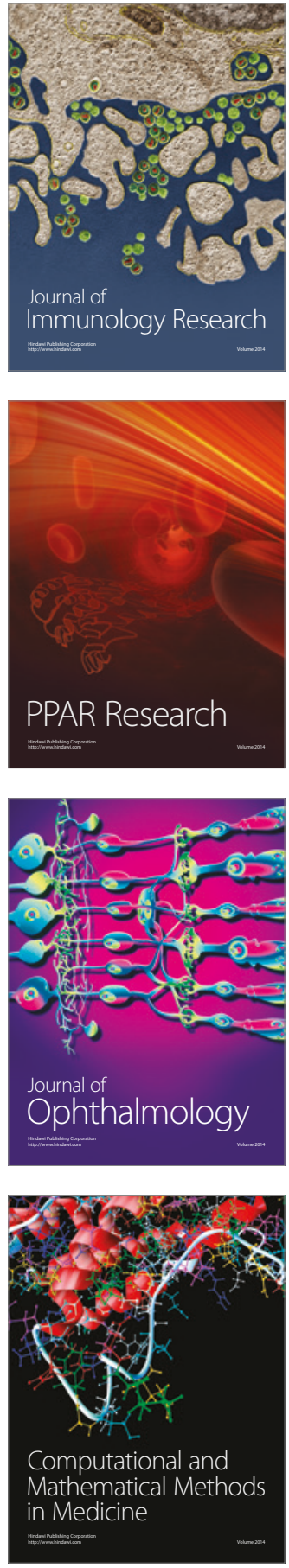

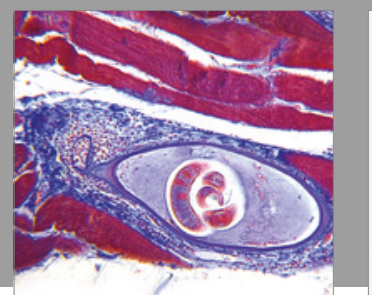

Gastroenterology Research and Practice
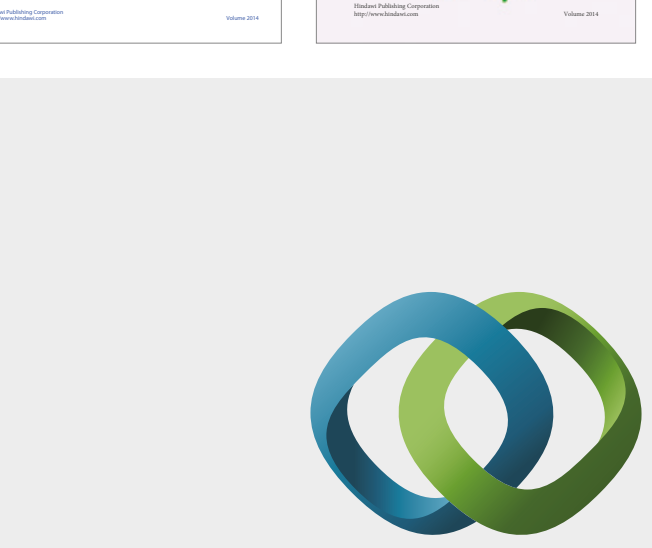

\section{Hindawi}

Submit your manuscripts at

https://www.hindawi.com
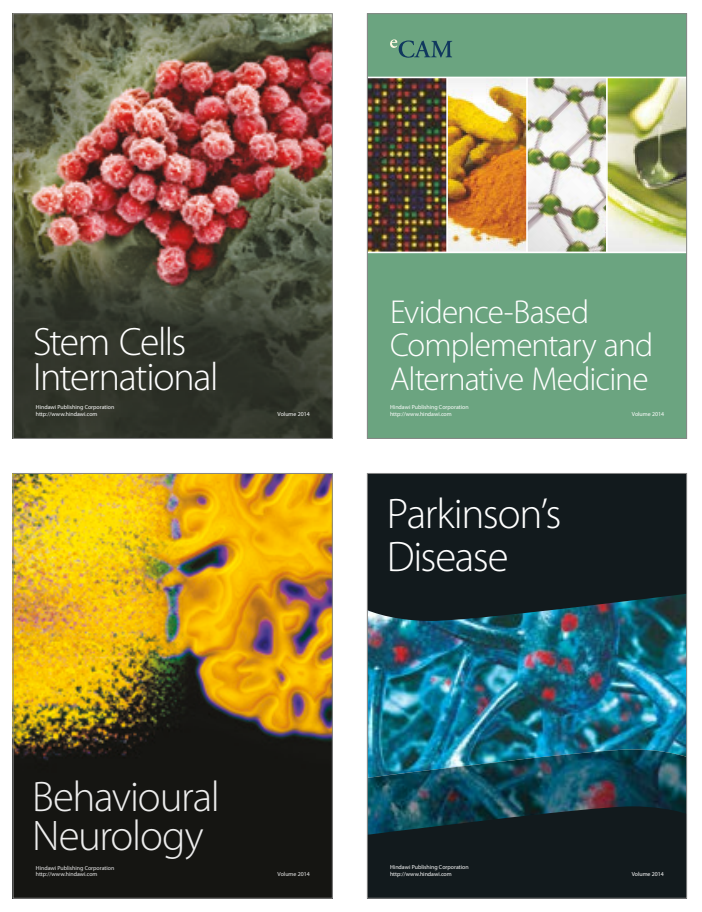
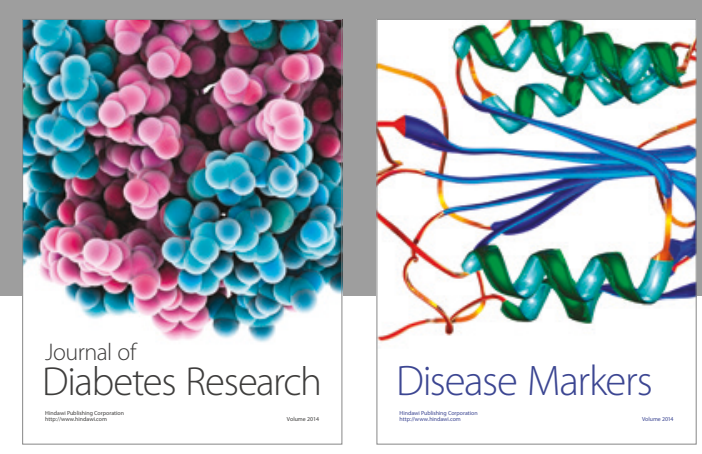

Disease Markers
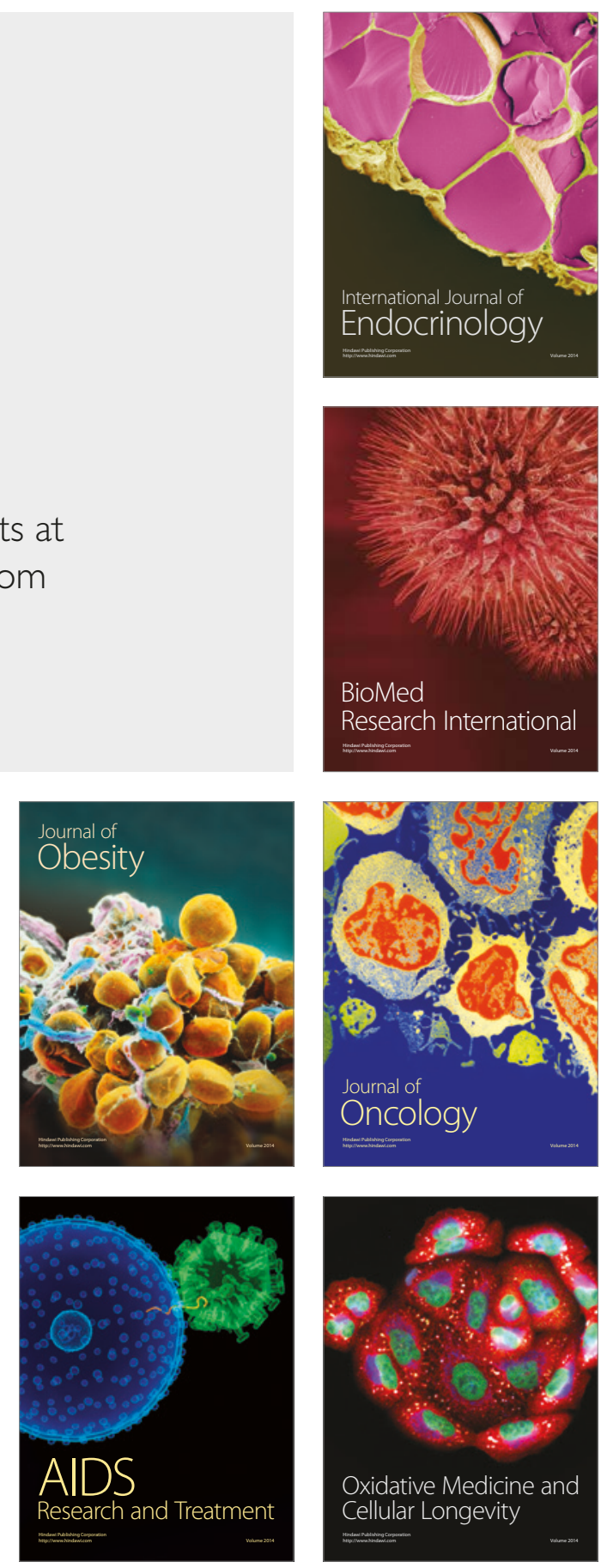